\title{
Erratum to: Immune monitoring technology primer
}

Kevin K. Dobbin

The title of the original version of this article [1] contained an error. The correct title should be "Immune Monitoring Technology Primer: Clinical Validation for Predictive Markers." The title has been corrected in the original article also.

Received: 29 October 2015 Accepted: 29 October 2015

Published online: 17 November 2015

\section{Reference}

1. Dobbin KK. Immune monitoring technology primer. J Immunother Cancer. 2015;3:40.

- Convenient online submission

- Thorough peer review

- No space constraints or color figure charges

- Immediate publication on acceptance

- Inclusion in PubMed, CAS, Scopus and Google Scholar

- Research which is freely available for redistribution 